\title{
A LINEÁRIS PROGRAMOZÁSI MODELL ALKALMAZÁSA A SZÁNTÓFÖLDI NÖVÉNYTERMESZTÉS OPTIMALIZÁLÁSÁNÁL A KÖZVETLEN TÁMOGATÁSOK FIGYELEMBEVÉTELE MELLETT
}

\author{
Csipkés Margit
}

\begin{abstract}
Absztrakt: A szántóföldi növénytermesztés vetésszerkezetének és jövedelmének egyidejü optimalizálására a lineáris programozást célszerü alkalmazni. A módszer segítségével meghatározható egy olyan optimális vetésszerkezet, amely megfelel a zöldítés feltételeinek, továbbá maximálisan kihasználja a támogatási lehetőségeket, így a lehető legnagyobb jövedelmet biztosítja a gazdálkodó számára. Általános célom az adott üzemméret mellett a lehetséges jövedelem maximalizálása. Elsö specifikus célkitüzésként a zöldborsó versenyképességét kívánom vizsgálni a termeléshez kötött ipari zöldségnövény termesztésének támogatásával figyelembe véve, illetve annak csökkentett mértével. Második specifikus célul a földbérlés gazdaságosságának meghatározását tüztem ki, meghatározott rendelkezésre álló töke és földbérleti díj mellett. Harmadik specifikus célul pedig a támogatások jövedelemre gyakorolt hatásának meghatározását tüztem ki.
\end{abstract}

Abstract: Linear programming should be applied in order to optimize the sowing structure and income of arable crops. This method can be used to determine an optimal sowing facility that meets the requirements for greening and maximizes the use of support options to provide the largest income for the farmer. The main goal of my paper is to maximize not only the potential income, but also the given plant size. The first specific objective is to look at the competitiveness of green peas, with the support of the production of industrial vegetable crops linked to production, and its reduced scale. My other specific aim is to determine the economics of land renting with a certain amount of available capital and land rent. My third specific goal was to determine the impact of subsidies on income.

Kulcsszavak: szántóföldi növénytermesztés, lineáris programozás, jövedelem

Keywords: arable cultivation, linear programming, income

\section{Bevezetés}

Kutatásomban különbözö szántóföldi kultúrák termesztésének vetésszerkezet és jövedelem optimalizálását választottam egy adott üzemméretre vonatkozóan. Magyarország 4,3 millió hektár szántóterületének, mintegy 50\%-án őszi búza és kukorica kerül elvetésre, továbbá jelentős szereppel bírnak az ipari növények, mint napraforgó és zöldborsó, így anyagomban az előzőekben felsorolt kultúrák vetésterület és jövedelem optimalizálását kívánom elvégezni. Az optimális vetésszerkezet meghatározásának jelentősége a Közös Agrárpolitika 2013-as reformját követően tovább fokozódott, hiszen a közvetlen támogatások keretében bevezetésre került a zöldítés. A támogatások maximális igénybevételéhez több feltételnek is meg kell felelni, így a vetésszerkezet és jövedelem tudományos alapon történő optimalizálása nagyobb gazdaságok esetén elengedhetetlen.

A közvetlen támogatások új rendszerével hazánkban is kötelezően alkalmazni kell a zöldítési jogcím feltételeit a támogatás igénybevételéhez. Ennek keretében a gazdaságoknak területmérettől függően be kell tartaniuk a diverzifikációra, ökológiai célterületekre és gyepmegőrzésre vonatkozó szabályozásokat, így azok a nagygazdaságok (30 hektár feletti területtel rendelkezök), amelyek korábban 
kizárólag őszi búzát és kukoricát termesztettek a teljes területuikön már nem felelnének meg a zöldítés feltételeinek, ezáltal jelentős támogatási összegtől esnének el.

A szántóföldi növénytermesztés vetésszerkezetének és jövedelmének egyidejü optimalizálására a lineáris programozást célszerü alkalmazni. A módszer segítségével meghatározható az az optimális vetésszerkezet, amely megfelel a zöldítés (diverzifikáció, ökológiai célterület és gyepmegőrzés) feltételeinek, továbbá maximálisan kihasználja a támogatási lehetőségeket, így a lehető legnagyobb jövedelmet biztosítja a gazdálkodó számára. A lineáris programozás használatával nem csak a zöldítés feltételei vehetök figyelembe, hanem a közvetlen támogatás keretében nyújtott további támogatások is, mint a területalapú támogatás vagy a termeléshez kötött ipari zöldségnövény termesztésének támogatása is. Általános célnak az adott üzemméret tekintetében lehetséges jövedelem maximalizálást tüztem $\mathrm{ki}$, amelyhez több specifikus célt is rendeltem. Első specifikus célkitüzésként a zöldborsó versenyképességét kívánom vizsgálni a termeléshez kötött ipari zöldségnövény termesztésének támogatásával figyelembe véve, illetve annak csökkentett mértével. Második specifikus célul a földbérlés gazdaságosságának meghatározását tüztem ki, meghatározott rendelkezésre álló tőke és földbérleti díj mellett. Harmadik specifikus célul pedig a támogatások jövedelemre gyakorolt hatásának meghatározását tüztem ki.

\section{Közvetlen támogatások rendszere}

Az Európai Unió közös agrárpolitikájának (KAP) három területe van, amelyek szervesen kapcsolódnak egymáshoz, így ezekből a területekből tevődik össze a KAP két pillére. Az I. pillért a piacszervezés és közvetlen támogatás, míg a II. pillért a vidékfejlesztés alkotja. A KAP összköltségvetésén és a tagállamok költségvetésén belül is a legnagyobb pénzügyi kerettel a közvetlen támogatások vannak jelen. A 2014-2020-as új költségvetési periódusban Magyarország számára rendelkezésre álló KAP forráskeret 12,3 milliárd euró, amelyből a közvetlen támogatásokra fordítható összeg 8,85 milliárd eurót $(\sim 72 \%)$ tesz ki, a vidékfejlesztésre pedig 3,45 milliárd euró ( 28\%) jut (Palakovics et al., 2016).

A közös agrárpolitika 2015-ös reformja több új feltételt és jogcímet is bevezetett a közvetlen támogatások körébe. Ennek keretében Magyarország a kötelező elemek közül a területalapú támogatás (SAPS), a zöld komponenst és a fiatalgazdálkodóknak juttatott támogatást, míg nemzetileg önkéntes elemként a termeléshez kötött támogatást vezette be. Ezeken kívül további önkéntes elemként jelent meg a kisgazdaságok számára egyszerüsített támogatási rendszer, míg a degresszivitás kötelezően alkalmazandó. A továbbiakban azok a támogatási elemek kerülnek bemutatásra, amelyek az általam készített lineáris programozási modell részét képzik (Potori, 2012).

\subsection{Területalapú támogatás}

Az igénybe vehető területalapú támogatás legalább 1 hektár terület megléte esetén lehetséges, de a minimálisan támogatható parcella méret 0,25 hektár. A SAPS 
keretében kifizethető összeg mértéke pedig 143 euró hektáronként. Minden egyéb közvetlen támogatás (zöldítés, termeléshez kötött zöldség-gyümölcs és fehérjenövény támogatása) csak SAPS jogosult területek után jár (Palakovics et al., 2016).

\subsection{Zöld komponens}

A zöldítési támogatásra jogosult területnagyság meghatározásakor az egységes területalapú támogatáshoz megállapított területet kell alapul venni. A zöldítés támogatásának összege 81 euró hektáronként, amely éves kifizetésü, vissza nem térítendő támogatás. A zöldítés alapvetően három különböző gyakorlat összessége. $\mathrm{Az}$ első része a terménydiverzifikáció, azaz a növénytermesztés diverzifikálása. Ennek keretében 10 hektár feletti szántóterületen legalább két növénykultúrát kell termeszteni, míg a 30 hektár feletti szántóterületen legalább három növénykultúrát. Két kultúra esetében a legnagyobb területen termesztett növénykultúra a szántóterület legfeljebb 75\%-át foglalhatja el. Három növénykultúra esetében a szántóterület legfeljebb $75 \%$-át foglalhatja el, a két legnagyobb területen termesztett növénykultúra, amelyek együttesen nem haladhatják meg a szántóterület $95 \%$-át. A zöldítés második része az ökológiai jelentőségủ területek kijelölése. Ennek keretében a 15 hektár feletti szántóterületen legalább 5\%-nak megfelelő ökológiai célterület kell kijelölni. A zöldítés harmadik része pedig az állandó gyepterületek megörzése, amely során az állandó gyepterületnek minősülő területeket mértékét meg kell őrizni. A zöldítés feltételei az 1. táblázatban láthatók (Internet_1).

\section{1. táblázat: Zöldítés feltételei}

\begin{tabular}{|c|c|c|c|}
\hline $\begin{array}{c}\text { Szántóterület } \\
\text { mérete }\end{array}$ & Terménydiverzifikáció & $\begin{array}{l}\text { Ökológiai } \\
\text { célterület }\end{array}$ & $\begin{array}{c}\text { Állandó } \\
\text { gyepmegőrzés }\end{array}$ \\
\hline$<10 \mathrm{ha}$ & - & - & \multirow[b]{4}{*}{$\begin{array}{l}\text { Minden állandó } \\
\text { gyepterületet } \\
\text { meg kell őrizni }\end{array}$} \\
\hline 10-15 ha & \multirow{2}{*}{$\begin{array}{l}\text { Legalább } 2 \text { növénykultúra } \\
\text { (legnagyobb növénykultúra } \\
\text { a terület legfeljebb } 75 \% \text {-án) }\end{array}$} & - & \\
\hline $15-30$ ha & & \multirow[b]{2}{*}{$\begin{array}{c}\text { Szántóterület } \\
\text { legalább 5\%- } \\
\text { ának } \\
\text { megfelelő } \\
\text { ökológiai } \\
\text { célterület } \\
\text { kijelölése }\end{array}$} & \\
\hline$>30$ ha & $\begin{array}{c}\text { legalább } 3 \text { növénykultúra } \\
\text { (legnagyobb növénykultúra } \\
\text { a terület legfeljebb 75\%-án, } \\
\text { a két legnagyobb } \\
\text { növénykultúra legfeljebb } \\
\text { 95\%-án) }\end{array}$ & & \\
\hline
\end{tabular}

Forrás: Palakovics et al., 2016

\subsection{Termeléshez kötött támogatás}

A termeléshez kötött ipari zöldségnövény támogatására való jogosultság feltétele, hogy minimum 0,3 hektáron folyjon a növény termesztése. A támogatás igénybevételéhez meghatározott kultúrák termesztése az irányadó, mint zöldborsó, csemegekukorica, zöldbab, szárazbab, spenót vagy sóska. Ezentúl, meghatározott hektáronkénti minimális vetőmag használat, illetve a vetőmag beszerzésének 
számlával történő igazolása kötelező. A támogatás mértéke a benyújtott vetésterületek és az adott évben rendelkezésre álló forráskeret alapján kerül meghatározásra, amely 2015-ben 164 euró volt hektáronként (Fodor, 2015).

\section{Anyag és módszer}

Vizsgálatom során négy különböző kultúra vetésszerkezetének és jövedelmének optimalizálását végeztem el. Az ezekhez szükséges adatok felhasználása pedig, szekunder adatgyüjtéseken nyugszik. A modell felépítéséhez a következő adatok kerültek begyüjtésre: különböző kultúrák technológiai terve, ráfordítások költségei, fajlagos hozamok, értékesítési árak és a támogatások összege.

A szántóföldi kultúrák technológiai terve és az inputanyagok beszerzési ára, továbbá a gépköltségek Apáti (2016) adatai alapján kerültek összeállításra, amelyre maga a modell is épül.

A fajlagos hozamok meghatározásánál az Agrárgazdasági Kutató Intézet által közölt Hajdú-Bihar megyei éves termésátlagok öt éves átlaghozamait használtam fel, amelyek a 2. táblázatban láthatóak.

\section{2. táblázat: Hajdú-Bihar megye termésátlagai (kg/ha)}

\begin{tabular}{|l|c|c|c|c|c|c|}
\hline \multirow{2}{*}{ Kultúra } & \multicolumn{7}{|c|}{ Hajdú-Bihar megye } \\
\cline { 2 - 7 } & $\mathbf{2 0 1 1}$ & $\mathbf{2 0 1 2}$ & $\mathbf{2 0 1 3}$ & $\mathbf{2 0 1 4}$ & $\mathbf{2 0 1 5}$ & Átlag \\
\hline Búza & 4400 & 4080 & 4700 & 5040 & 5150 & $\mathbf{4 6 7 4}$ \\
\hline Kukorica & 6910 & 5190 & 6080 & 6920 & 6070 & $\mathbf{6 2 3 4}$ \\
\hline Napraforgó & 2710 & 2640 & 2990 & 2870 & 3390 & $\mathbf{2 9 2 0}$ \\
\hline Zöldborsó & 7280 & 6740 & 5210 & 5040 & 5800 & $\mathbf{6 0 1 4}$ \\
\hline
\end{tabular}

Forrás: Saját szerkesztés AKI, 2017 alapján

Értékesítési arrak tekintetében a Budapesti Értéktőzsde és FAOSTAT által közölt adatok kultúránkénti öt éves átlagárait vettem alapul. A 2012-2016 között a búza értékesítési átlagárai 40631 és $60383 \mathrm{Ft} /$ tonna között ingadozott, amely öt éves átlagban $49702 \mathrm{Ft} /$ tonna értéket eredményezett. Ugyanezen időszak alatt a kukorica értékesítési átlagárai 43672 és 59811 Ft/tonna között alakultak, amely öt éves átlagban $49591 \mathrm{Ft} / t o n n a$ átlagárat indukált. Ezzel ellentétben a napraforgó értékesítési átlagárai a 2012-2016 közötti időszakra vonatkozóan 91593 és $129612 \mathrm{Ft} /$ tonna között ingadoztak, így az ötéves átlaga $109852 \mathrm{Ft} /$ tonna volt. A zöldborsó esetében a FAOSTAT adatai alapján a 2011-2015-ös évekre vonatkozó értékesítési átlagárai 71910 és $91686 \mathrm{Ft} /$ tonna között alakultak, amely értékek ötéves átlagban 84063 Ft tonnánkénti átlagárat eredményeztek.

Az egyes kultúrák vetésszerkezetének, illetve jövedelem optimalizálásához az operációkutatás egyik módszerét a lineáris programozást használtam fel, Excel program segítségével. A lineáris programozás alkalmas arra, hogy adott tevékenységek halmazán belül meghatározzuk a célfüggvény maximumát vagy minimumát az egyes tevékenységekhez rendelt erőforrások és azok korlátozása mellett (Bajalinov-Bekéné, 2010), amelynek alapsémája a 3. táblázatban látható. 
3. táblázat: A lineáris programozási modell alapsémája

\begin{tabular}{|c|c|c|c|c|c|c|c|}
\hline & $\mathbf{x 1}$ & $\mathbf{x 2}$ & & $\mathbf{x 3}$ & Felhasználás & Reláció & Kapacitás \\
\hline $\mathbf{u 1}$ & & & & & ${ }^{*} \underline{x}$ & $<=$ & \\
\hline $\mathbf{u} 2$ & & & & & ${ }^{\underline{x}}$ & $<=$ & \\
\hline $\mathbf{u 3}$ & & & & & ${ }^{*} \underline{\underline{x}}$ & $<=$ & \\
\hline CF & & & & & $\underline{\underline{p}}^{*} \underline{\mathrm{x}}$ & MAX! & \\
\hline Megoldás & & \multicolumn{3}{|c|}{$\underline{x}$} & & & \\
\hline
\end{tabular}

Forrás: Saját szerkesztés, 2017

A lineáris programozási modell felépítéséhez első lépésként azonosítani szükséges az egyes tevékenységeket (Ferenczi, 2006), más néven változókat (x1, x2, x3 stb.), amelyek alapján optimalizálni kívánjuk a célfüggvényt. Az általam alkalmazott modellben a négy kultúra (búza, kukorica, napraforgó, zöldborsó), a parlagoltatás, továbbá az igénybe vehető támogatási jogcímek kerültek meghatározásra változókként.

$\mathrm{Az}$ egyes tevékenységekhez meg kell határozni második lépésben a szükséges erőforrásokat (u1, u2, u3 stb.), illetve azok mennyiségét (anm), amelyeket a technológiai mátrixban szükséges elhelyezni (Glevitzky, 2003).

A modell célfüggvény sora az egyes változók azon értékeit (p1, p2, p3 stb.) tartalmazhatják, amelyek alapján optimalizálni kívánjuk a modellt is (Rapcsák, 1988). Ez a legtöbb esetben valamilyen költség vagy jövedelemkategória. Jelen modell esetében az egyes kultúrák hektáronként realizálható fedezeti összege, valamint az egy hektárra jutó támogatások összege.

A kapacitás oszlopba (b1, b2, b3 stb.), az egyes erőforrásokból rendelkezésre álló mennyiséget szükséges meghatározni, ahova nem csak felső értéket, hanem akár minimálisan felhasználandó értéket is meglehet határozni. A vetésterület kialakításánál a kapacitás értékek a rendelkezésre álló, illetve felhasználandó vagy felhasználható területek nagyságát jelöli.

Azt, hogy a rendelkezésre álló kapacitásból mekkora mennyiség kerül felhasználásra az a felhasználásból olvasható majd ki. A modell optimalizálása az Excel program Solver bővítményével lehetséges.

\section{Eredmények és értékelésük}

Anyagomban négy különböző szántóföldi kultúra - búza (B), kukorica (K), napraforgó $(\mathrm{N})$ és zöldborsó $(\mathrm{Z})$ - vetésszerkezet és jövedelem optimalizálását végeztem el, amely mellett a parlagoltatás is megjelent, mint lehetséges zöldítési feltétel. Számításaimban meghatároztam az egyes kultúrák egy hektárra jutó ráfordítás szükségleteit (inputanyagokat, gépi- és személyi jellegü ráfordításokat), azok mértékegységét és az egységnyi ráfordítás költségét.

Az egyes kultúrák várható hozamainál a Hajdú-Bihar megyei 2011 és 2015 közötti termésátlagainak az átlagát vettem számításom alapjául, amely kiküszöböli az időjárás változás által bekövetkezett szélsőséges értékeket. A búza esetén $4555 \mathrm{~kg} /$ ha, kukoricánál $6234 \mathrm{~kg} / \mathrm{ha}$, napraforgónál $2920 \mathrm{~kg} / \mathrm{ha}$, míg a zöldborsó tekintetében $6014 \mathrm{~kg} / \mathrm{ha}$ a termésátlag, amelyek a 4. táblázatban láthatók. 
Parlagoltatás esetén nem keletkezik érdemi hozam és bevétel, így az a táblázatban nem került feltüntetésre.

\section{4. táblázat: Szántóföldi kultúrák termésátlagai Hajdú-Bihar megyében (kg/ha)}

\begin{tabular}{|l|c|c|c|c|c|c|}
\hline Kultúra & $\mathbf{2 0 1 1}$ & $\mathbf{2 0 1 2}$ & $\mathbf{2 0 1 3}$ & $\mathbf{2 0 1 4}$ & $\mathbf{2 0 1 5}$ & Átlag \\
\hline Búza & 4400 & 4080 & 4700 & 5040 & 5150 & $\mathbf{4 5 5 5}$ \\
\hline Kukorica & 6910 & 5190 & 6080 & 6920 & 6070 & $\mathbf{6 2 3 4}$ \\
\hline Napraforgó & 2710 & 2640 & 2990 & 2870 & 3390 & $\mathbf{2 9 2 0}$ \\
\hline Zöldborsó & 7280 & 6740 & 5210 & 5040 & 5800 & $\mathbf{6 0 1 4}$ \\
\hline
\end{tabular}

Forrás: Saját szerkesztés AKI, 2017 adatai alapján

Az egyes kultúrák értékesítési árának meghatározásánál szintén az elmúlt évek adatait vettem alapul, amelyek értéke az 5 . táblázatban látható. A búza esetén $49702 \mathrm{Ft} / t$, a kukoricánál $49591 \mathrm{Ft} / \mathrm{t}$, a napraforgónál $109852 \mathrm{Ft} / \mathrm{t}$, míg a zöldborsó tekintetében $84063 \mathrm{Ft} / \mathrm{t}$ az átlagos értékesítési ár.

5. táblázat: Szántóföldi kultúrák átlagos értékesítési ára (Ft/tonna)

\begin{tabular}{|l|c|c|c|c|c|c|c|}
\hline \multicolumn{1}{|c|}{ Kultúra } & $\mathbf{2 0 1 1}$ & $\mathbf{2 0 1 2}$ & \multicolumn{1}{c|}{2013} & $\mathbf{2 0 1 4}$ & $\mathbf{2 0 1 5}$ & \multicolumn{1}{c|}{$\mathbf{2 0 1 6}$} & \multicolumn{1}{c|}{ Átlag } \\
\hline Búza & - & 60383 & 53912 & 47197 & 46385 & 40631 & $\mathbf{4 9 7 0 2}$ \\
\hline Kukorica & - & 59810 & 52478 & 46296 & 45700 & 43671 & $\mathbf{4 9 5 9 1}$ \\
\hline Napraforgó & - & 129612 & 109804 & 91592 & 110377 & 107876 & $\mathbf{1 0 9 8 5 2}$ \\
\hline Zöldborsó & 71909 & 84151 & 86666 & 91686 & 85904 & - & $\mathbf{8 4 0 6 3}$ \\
\hline
\end{tabular}

Forrás: Saját szerkesztés BÉT, 2017 és FAOSTAT, 2016 adatai alapján

A négy kultúra termesztésére 150 hektár szántóterület áll rendelkezésre, amelyet teljes mértékben felhasználásra kerül. Az egyes kultúrák értékesítéséböl származó bevételeken túl a közvetlen támogatások keretében lehívható összegeket a 6. táblázat tartalmazza. A területalapú támogatás termelési feltétel nélkül igényelhető, tehát nem kívánja egy meghatározott növénykultúra termesztését. Az egy hektárra jutó területalapú támogatás összege 44208 Ft (309,15 Ft/euró árfolyamot alkalmazva a támogatások esetén).

A zöldítés keretében különböző feltételeknek szükséges megfelelni, mind diverzifikáció, mind ökológiai célterület kialakításának tekintetében. Az általam alkalmazott modell, ezen elvárásokat teljesíti, ezáltal hektáronként $25041 \mathrm{Ft}$ támogatással lehet számolni, hiszen a parlagon hagyott terület alkalmazásával a minimális területmérték egyszeres szorzófaktorral rendelkezik.

Zöldborsó termelése esetén lehetöség van termeléshez kötött ipari zöldségnövény termesztéséhez kapcsolódó támogatás igénybevételére, amelynek mértéke a rendelkezésre álló forráskeret és az ipari zöldségnövények országos vetésterületének hányadosával egyezik meg. A 2015-ös évben ennek mértéke $50701 \mathrm{Ft}$ volt hektáronként, így a modellemben is ezen értéket vettem számításom alapjául. 


\section{6. táblázat: Közvetlen támogatások mértéke}

\begin{tabular}{|l|c|}
\hline Támogatási jogcím & Támogatási összeg (Ft/ha) \\
\hline Területalapú támogatás & 44208 \\
\hline Zöldítés parlagoltatással (1x szorzófaktor) & 25041 \\
\hline Termeléshez kötött ipari zöldségnövény termesztés & 50701 \\
\hline
\end{tabular}

Forrás: Palakovics et al., 2016

Ahhoz, hogy a közvetlen támogatások összegét a SAPS támogatásra jogosult területek teljes egészére igénybe lehessen venni, szükséges a zöldítés feltételeinek betartása, amelyek az 1. táblázatban láthatók.

Mivel a szántóterület ( 150 hektár) a jelenlegi modellben meghaladja a 30 hektárt, így mind a diverzifikációnak és az ökológiai célterület kialakításának meg kell felelni. Mivel jelen esetben nem áll rendelkezésre állandó gyepterület, így ennek befolyásoló hatásával nem foglalkoztam a modell során. Diverzifikáció tekintetében legalább három különböző növénykultúra termesztése kötelező úgy, hogy a legnagyobb területen termesztett növény a szántó legfeljebb 75\%-án lehet, míg az első és második kultúra a szántó legfeljebb 95\%-át foglalhatja el.

Az ökológiai jelentőségủ célterület kialakítása a szántóterület legalább 5\%-án kötelező, amely esetben parlagoltatást alkalmaztam, így a SAPS támogatásra jogosult területekre egyszeres szorzófaktorral rendelkezỏ zöldítési támogatás hívható le.

Fontos megjegyezni, hogy az ökológiai célterületnél alkalmazott kultúra vagy egyéb müvelés egyszerre elégíti ki az ökológiai célterület és diverzifikáció feltételeit, így a parlagoltatás is megfelel, mint ökológiai célterület és a diverzifikáció harmadik eleme.

A lineáris programozási modell elkészítése előtt meghatároztam az egyes kultúrák és a parlagoltatás közvetlen költségeit (szorzatösszeg függvény alkalmazásával), majd pedig a fedezeti összegüket hektárra vetítve, továbbá az egyes támogatási összegeket.

\subsection{Alapmodell}

A modell elkészítésénél nyolc különböző változó (oszlopok) került bevezetésre, mégpedig a búza, kukorica, napraforgó, zöldborsó, parlagoltatás és az egyes támogatások, mint SAPS, termeléshez kötött támogatás, valamint a zöldítés.

$\mathrm{Az}$ összes terület esetén az érték a feladatleírás alapján 150 hektárban került meghatározásra, amelyet teljes egészében felhasználtam. A területeken pedig búza, kukorica, napraforgó, zöldborsó termelésére és parlagoltatásra van lehetőség.

A következő erőforrásként a területalapú támogatás került felvezetésre, amelynek területi mérete megegyezik az összes területtel, továbbá ezen támogatás igénylése független a termeléstől.

Ahhoz, hogy a zöldítési támogatás feltételeinek megfeleljen a modell, ökológiai célterület került kialakításra, parlagoltatás kialakításával, amelynek legalább 5\%-nak kell lennie az összes területre vonatkozóan, továbbá a parlag terület elfogadható a diverzifikáció során elöírt harmadik kultúrának. 
Mivel a diverzifikációt és az ökológiai célterületet is teljesíti a modell, így az erőforrásként bevezetett zöldítési támogatást is igénybe lehet venni az összes terület után.

A termeléshez kötött ipari zöldség támogatását kizárólag azokra a területekre lehet igénybe venni, amelyeken zöldborsó termelése folyik, így annak területi korlátja a zöldborsó területi erőforrása alapján került áthivatkozásra.

A diverzifikáció elöírja, hogy a legnagyobb területen termesztett növény a terület legfeljebb 75\%-án termeszthetö, ezáltal az összes terület maximum 75\%-ában van lehetőség búza, kukorica, napraforgó és zöldborsó termesztésére. További feltételként került bevezetésre, hogy a két legnagyobb területen termesztett kultúra együttes aránya nem haladhatja meg a $95 \%$-ot.

A relációk ezen feltételek mentén kerültek meghatározásra, továbbá a terület kapacitások az összes területre vonatkozóan dinamikusan lettek felvezetve a modellbe.

Célfüggvényként a négy kultúra és a parlagterület esetében a hektáronkénti fedezeti összegük, míg az egyes támogatások tekintetében azok hektáronkénti összegük került meghatározásra.

A modell elkészítését követően a program megoldását az Excel program Solver bővítményével kaptam meg.

A program futtatásával kapott célérték összege $24531659 \mathrm{Ft}$, tehát az adott vetésszerkezet mellett ekkora bevétel érhetö el 150 hektáron. Az optimális vetésszerkezet alapján elmondható, hogy 112,5 hektáron zöldborsó, 30,0 hektáron napraforgó és 7,5 hektáron parlag terület kialakítása szuikséges.

A területalapú és zöldítés támogatására jogosult területek mértéke 150 ha, míg a termeléshez kötött támogatásra jogosult terület 112,5 hektár, amely a zöldborsó vetésterülete alapján igényelhetö. A négy kultúra és a parlag területek összege pontosan 150 hektár. Ezen belül 75\%-ot képvisel a zöldborsó, 20\%-ot a napraforgó és 5\%-ot a parlagon hagyott területek aránya.

\section{2. Érzékenységjelentés 1 .}

A lineáris program megoldásával egyidejüleg Érzékenységjelentés került lekérdezésre, amely két részből áll, mégpedig a módosuló cellák és a korlátozó feltételek nevü táblázatokból. A módosuló cellák táblázata az egyes változókról ad információkat, amely a 7. táblázatban látható.

Azoknál a változóknál, amelyek nem rendelkeznek végső végértékkel, azok a változók nem kerültek be a modellbe, így redukált költséggel rendelkeznek. Amint látható, a búza nem került be az optimális megoldásba, a megengedhető növelés és redukált költség $34612 \mathrm{Ft} /$ ha-os értéke azt jelenti, hogy ezen értékkel $76109 \mathrm{Ft} / \mathrm{ha}$ os összegre növelve a búza célfüggvényét az biztos bekerül az optimális megoldásba.

A kukorica szintén nem rendelkezik végső végértékkel, így nincs benne az optimális megoldásban sem. Ezzel egyidejüleg redukált költséggel sem rendelkezik, amely arról árulkodik, hogyha a búza célfüggvény értéke növelésre kerül a redukált költség értékével, akkor a búza és kukorica célfüggvény értéke megegyező lesz, így 
alternatív optimum keletkezik. Alternatív optimum esetén pedig megoszlási viszonyszámok segítségével, végtelen mennyiségü optimális megoldás indukálható.

7. táblázat: Alapmodell érzékenységjelentésének módosuló cellái

\begin{tabular}{|c|c|c|c|c|c|}
\hline Név & $\begin{array}{c}\text { Végső } \\
\text { Érték }\end{array}$ & $\begin{array}{c}\text { Csökkentett } \\
\text { költség }\end{array}$ & $\begin{array}{c}\text { Célérték } \\
\text { együtthatója }\end{array}$ & MN & MCS \\
\hline Búza & 0 & $-34611,54$ & 41497,35 & 34611,54 & $1,00 \mathrm{E}+30$ \\
\hline Kukorica & 0 & 0 & 76108,89 & 7925,63 & 34611,54 \\
\hline Napraforgó & 30 & 0 & 84034,52 & 21347,66 & 7925,63 \\
\hline Zöldborsó & 112,5 & 0 & 54681,58 & $1,00 \mathrm{E}+30$ & 21347,66 \\
\hline Parlagoltatás & 7,5 & 0 & -30975 & 107083,89 & $1,00 \mathrm{E}+30$ \\
\hline $\begin{array}{c}\text { Területalapú } \\
\text { támogatás }\end{array}$ & 150 & 0 & 44208,45 & $1,00 \mathrm{E}+30$ & $1,00 \mathrm{E}+30$ \\
\hline $\begin{array}{c}\text { Termeléshez } \\
\text { kötött } \\
\text { támogatás }\end{array}$ & 112,5 & 0 & 50700,6 & $1,00 \mathrm{E}+30$ & 21347,66 \\
\hline $\begin{array}{c}\text { Zöldítés } \\
\text { támogatás }\end{array}$ & 150 & 0 & 25041,15 & $1,00 \mathrm{E}+30$ & $1,00 \mathrm{E}+30$ \\
\hline
\end{tabular}

*MN: Megengedhető növelés; MCS: Megengedhető csökkentés

Forrás: Saját szerkesztés, 2017

Mivel a napraforgó, zöldborsó és a parlagon hagyott terület végső végértékkel rendelkezik, így azok benne lesznek az optimális megoldásban. A megengedhető és csökkenés értékük pedig arról árulkodik, mennyivel szükséges növelni vagy csökkenteni a célfüggvény értéküket, hogy az optimális megoldásban betöltött szerepük megváltozzon. $\mathrm{Az} 1 \mathrm{E}+30$ érték pedig szintén azt jelenti, hogy bármennyivel is változtatva azok értékét az optimális megoldásban betöltött szerepük nem fog módosulni.

A területalapú támogatás és zöldítés esetében a megengedhető növekedés és csökkenés is végtelen értéket vett fel, hiszen ezen változók célfüggvény értékének módosulása nincs hatással az egyéb változókra és azok modellben betöltött szerepére.

A termeléshez kötött támogatás esetében a megengedhető növekedés és csökkenés értéke a zöldborsóval megegyezö, hiszen azok megoldás értékének is megegyezőnek kell lennie. Ennek alapján, ha a zöldborsó vagy a termeléshez kötött támogatás célfüggvény értékét hektáronként 21348 Ft-tal csökken, akkor azok modellben betöltött szerepe is módosulni fog.

Abban az esetben, ha az erőforrás végső érték és korlátozó feltétel értéke egyenlö, abban az esetben szükkeresztmetszet alakul ki, így árnyékárral fog rendelkezni. Az árnyékár megmutatja, hogy az adott erőforrás kapacitás értékének egy egységnyi változtatásával, mennyivel változik a célfüggvény értéke.

Látható, hogy a búza, kukorica, napraforgó esetén nem került kihasználásra a 112,5 hektáros (legfeljebb 75\%-os) terület, így ezen növények kapacitás értékét 
bármennyivel is növelve a célfüggvény nem fog változni, hiszen nem rendelkeznek árnyékárral.

A zöldborsó esetében a 112,5 ha teljes mértékben kihasználásra került, így ezen kultúra terület kapacitás értékét a megengedhető növekedés és csökkenés intervallumán belül ( +30 és $-82,5$ ha) változtatva egy egységnyi változtatásával a modell célértéke $21348 \mathrm{Ft}$-tal módosul, anélkül, hogy a zöldborsó modellben betöltött szerepe módosulna ( 8 . táblázat).

8. táblázat: Alapmodell érzékenységjelentésének korlátozó feltételi

\begin{tabular}{|l|c|c|c|c|c|}
\hline \multicolumn{1}{|c|}{ Név } & $\begin{array}{c}\text { Végső } \\
\text { Érték }\end{array}$ & $\begin{array}{c}\text { Árnyék- } \\
\text { ár }\end{array}$ & $\begin{array}{c}\text { Korlátozó } \\
\text { feltétel jobb } \\
\text { oldal }\end{array}$ & MN & MCS \\
\hline $\begin{array}{l}\text { Búza és } \\
\text { Kukorica }\end{array}$ & 0 & 0 & 142,5 & $1,00 \mathrm{E}+30$ & 142,5 \\
\hline $\begin{array}{l}\text { Búza és } \\
\text { Napraforgó }\end{array}$ & 30 & 0 & 142,5 & $1,00 \mathrm{E}+30$ & 112,5 \\
\hline $\begin{array}{l}\text { Búza és } \\
\text { Zöldborsó }\end{array}$ & 112,5 & 0 & 142,5 & $1,00 \mathrm{E}+30$ & 30 \\
\hline $\begin{array}{l}\text { Kukorica és } \\
\text { Napraforgó }\end{array}$ & 30 & 0 & 142,5 & $1,00 \mathrm{E}+30$ & 112,5 \\
\hline $\begin{array}{l}\text { Kukorica és } \\
\text { Zöldborsó }\end{array}$ & 112,5 & 0 & 142,5 & $1,00 \mathrm{E}+30$ & 30 \\
\hline $\begin{array}{l}\text { Napraforgó és } \\
\text { Zöldborsó }\end{array}$ & 142,5 & 7925,63 & 142,5 & 0 & 30 \\
\hline Összes terület & 150 & 76108,89 & 150 & 30 & 0 \\
\hline $\begin{array}{l}\text { Területalapú } \\
\text { támogatás }\end{array}$ & 150 & 44208,45 & 150 & $1,00 \mathrm{E}+30$ & 150 \\
\hline $\begin{array}{l}\text { Zöldítés } \\
\text { parlagoltatás }\end{array}$ & 7,5 & 107083,9 & 7,5 & 0 & 7,5 \\
\hline $\begin{array}{l}\text { Zöldítés } \\
\text { támogatás }\end{array}$ & 150 & 25041,15 & 150 & $1,00 \mathrm{E}+30$ & 150 \\
\hline $\begin{array}{l}\text { Termeléshez } \\
\text { kötött } \\
\text { támogatás }\end{array}$ & 112,5 & 50700,6 & 0 & $1,00 \mathrm{E}+30$ & 225 \\
\hline Búza & 0 & 0 & 112,5 & $1,00 \mathrm{E}+30$ & 112,5 \\
\hline Kukorica & 0 & 0 & 112,5 & $1,00 \mathrm{E}+30$ & 112,5 \\
\hline Napraforgó & 30 & 0 & 112,5 & $1,00 \mathrm{E}+30$ & 82,5 \\
\hline Zöldborsó & 112,5 & 21347,66 & 112,5 & 30 & 82,5 \\
\hline
\end{tabular}

*MN: Megengedhető növelés; MCS: Megengedhető csökkentés

Forrás: Saját szerkesztés, 2017

Azokban az esetekben, ahol két növénykultúra területkapacitása került korlátozásra (búza-kukorica, búza-napraforgó, búza-zöldborsó, kukorica-napraforgó 
és kukorica-zöldborsó) látható, hogy a meghatározott területkapacitás nem került teljes mértékben felhasználásra, így azok kapacitás értékét bármennyivel is növelve a célfüggvény értéke nem változik.

A napraforgó és zöldborsó esetében azonban teljes mértékben felhasználásra került a területkapacitás, így árnyékárral rendelkezik. A megengedhető növekedés és csökkenés intervallumán belül ( +0 és -30 ha) változtatva annak kapacitás értékét a modell célfüggvény értéke egy egységnyi változtatással 7926 Ft-tal változik anélkül, hogy az adott erőforrás modellben betöltött szerepe módosulna.

$\mathrm{Az}$ összes terület, mint eröforrás is teljes mértékben felhasználásra került, így a megengedhető növekedés és csökkenés intervallumán (+30 és -0 ha) változtatva annak kapacitás értékét, az egységnyi változtatással a célfüggvény érték 76109 Fttal változik.

Az egyes támogatási jogcímek (SAPS, zöldítés és termeléshez kötött támogatás) területe is teljes mértékben felhasználásra került, hiszen az első kettőt csak az összes terület, míg az utolsót a zöldborsó terület felhasználása alapján lehet igényelni.

A parlagoltatás minimum $5 \%$-os területe $(7,5 \mathrm{ha})$ is teljes mértékben kihasználódott, így ezen erőforrás is árnyékárral rendelkezik. A kapacitás értékét a megengedhető növekedés és csökkenés értékén ( +0 és $-7,5$ ha) belül változtatva a modell célfüggvény értéke -107 804 Ft-tal változik.

\section{Következtetések, összegzés, záró megjegyzések, záró gondolatok}

Anyagomban a közvetlen támogatások szerepét és hatását vizsgáltam négy szántóföldi kultúra vetésszerkezet és jövedelem optimalizálásának tekintetében. A modellem során 150 hektár területkapacitáson négy kultúra vetésterülete került optimalizálásra fajlagos fedezeti összegük alapján, amely egyidejüleg megfelel a zöldítés által elöírt diverzifikáció és ökológiai célterület kialakításával kapcsolatos elöŕrásoknak, továbbá beépítésre került a területalapú támogatás és a termeléshez kötött ipari zöldségnövény termesztésének támogatása a modellbe.

$\mathrm{Az}$ alapmodell esetén 150 hektárból az optimális megoldás alapján 112,5 hektáron (75\%) zöldborsó, 30,0 hektáron (20\%) napraforgó került termesztésre, illetve 7,5 hektár (5\%) a parlagon hagyott terület. A búza és kukorica alacsony fedezeti összeg és termeléshez kötött támogatás hiányába nem került be az optimális megoldásba. Ezen vetésszerkezettel és a támogatások igénybevételével a célfüggvény értéke $24531659 \mathrm{Ft}$.

\section{Irodalomjegyzék}

Apáti F. (2016): Mezőgazdasági ágazatok gazdaságtana I. előadás. Debreceni Egyetem, Gazdaságtudományi Kar, Debrecen, 2016.09.15.-2016.12.05.

Bajalinov E., Bekéné R. A. (2010): Operációkutatás $I$. <http://www.tankonyvtar.hu/ en/tartalom/tamop425/0046_operaciokutatas 1/0046_operaciokutatas1.pdf> (2017.09.11.)

Ferenczi F. (2006): Operációkutatás. <http://www.sze.hu/ -kundi/opkut_jegyzetek/ Oper\%E1ci\%F3kutat\%E1s.pdf> (2017.09.17.)

Fodor Z. (2015): Termeléshez kötött támogatások a kertészeti ágazatban 2015-2020. Budapest. <http://www.nak.hu/images/Kamara/Letoltheto/2015_01_30_NAK

_zgy_termkot_tamogatas_AGROmashEXPO.pdf> (2017.07.20.). 
Glevitzky B. (2003): Operációkutatás I. <https://gyires.inf.unideb.hu/mobiDiak/ GlevitzkyBela/Operaciokutatas-1/opkut1.pdf> (2017.10.10).

Internet_1: Zöldítés Gazdálkodási Kézikönyv. <http://www.nak.hu/kiadvanyok/ kiadvanyok/411zoldites-gazdalkodoi-kezikonyv/file>

KSH (2016): Mezőgazdasági termöföldárak és bérleti díjak, 2015 <http://www.ksh.hu/docs/hun/xftp/stattukor/mgfoldarak/mgfoldarak15.pdf> (2017.08.21.).

Palakovics Sz. - Fodor Z. - Takács A. (2016): Közvetlen Támogatások Gazdálkodói Kézikönyv. Nemzeti Agrárgazdasági Kamara, Budapest.

Potori N. (2012): Közös Agrárpolitika 2014-2020: A reformtervezetek alapján várható hatások és kihívások Magyarországon. <http://www.ctosz.hu/html/jog/ eu/KAP_20142020_TERVEZET_2012.05..pdf> (2017.04.18.)

Rapcsák T. (1988): Az operációkutatás kialakulásáról és hazai helyzetéröl. <http://www.inf.uszeged.hu/ csendes/rapcsak.htm> (2017.08.10.) 